\title{
The Protection of Cruise Passengers and the Athens Convention
}

\author{
Erxiu Zeng \\ Centre for International Shipping Policy and Law Studies, School of Law, South China Normal University, Guangzhou, China \\ Email: zengerxiu@m.scnu.edu.cn
}

How to cite this paper: Zeng, E. X. (2018). The Protection of Cruise Passengers and the Athens Convention. Beijing Law Review, 9, 709-725.

https://doi.org/10.4236/blr.2018.95039

Received: October 10, 2018

Accepted: December 3, 2018

Published: December 6, 2018

Copyright $\odot 2018$ by author and Scientific Research Publishing Inc. This work is licensed under the Creative Commons Attribution International License (CC BY 4.0).

http://creativecommons.org/licenses/by/4.0/

\begin{abstract}
The partly application of the Athens Convention 1974 by Shanghai Maritime Court in Miss Yang v Cruise PLC reflected some problems relating to the application of the Athens Convention 1974 in China and its protection for the cruise passengers. With the popularization of cruise vacation and the development of cruise industry, issues relating to the protection of cruise passengers gain growing attentions. Law application and jurisdiction is essential for the protection of cruise passengers. This paper will discuss the need for legal protection of cruise passengers versus carriers, and explore the application of the Athens Convention 1974 to cruise passengers, in particular, the relations between its application and choice of law, its protection for passengers in choosing the court. This paper will carry out a comparative study on the issue of the application of the Athens Convention 1974 to cruise passengers and the issue of its direct effect and supremacy in China and UK. It concludes that the Athens Convention 1974 is applicable to cruise passengers, it shall have direct effect and supremacy in Chinese court, and China should accede to the 2002 Protocol to the Athens Convention 1974 for better protection of the cruise passengers.
\end{abstract}

\section{Keywords}

Cruise Passenger, Athens Convention 1974, Choice of Law, Jurisdiction Agreement, Forum Shopping

\section{Introduction}

With the popularization of cruise vacation, the number of cruise passengers has been growing rapidly and steadily. According to Cruise Lines International Association (CLIA), the official global cruise industry "has surpassed the 2017 ocean cruise passenger projections, reaching 26.7 million cruise passengers glo- 
bally up from a projection of 25.8 million. For 2018, based on the new vessel launch schedule and expected regional deployment, CLIA is projecting another positive year-over-year growth for the industry with a passenger forecast of 28 million" (CLIA, 2018). With the development of cruise industry, issues relating to the protection of cruise passengers gain glowing attentions, including not only the services they are provided with but also the safety of cruise travelling.

Cruise vacation may be only a cruise arrangement or a travel package centering on cruise tour; cruise vacationer may book a cruise vacation directly with a cruise line, or with a travel agency especially in the case of a travel package. In Miss Yang v Carnival PLC ${ }^{1}$, the plaintiff and her mother made a travelling abroad contract with China Travel Service Zhejiang Group Co. Ltd. purchasing travel product for cruise tour departing from Shanghai to Jeju, then to Fukuoka and returning to Shanghai on Blue Diamond Princess, a cruise ship operated by the defendant Carnival PLC. In Lawrence v NCL (Bahamas) Ltd. (the "Norwegian Jade") ${ }^{2}$, the claimant booked a cruise and stay package holiday with the Flights and Packages Ltd. to include flights from the UK to Venice, hotel accommodation in Venice, a cruise in the Mediterranean, departing from Venice on Norwegian Jade, a cruise ship operated by the defendant (NCL) and returning to Venice with return flights to the UK. In these two cases, the passengers did not make contracts directly with the cruise line. However, the bookings of the cruise tour need to be confirmed by the cruise line to carry out the contract between the passengers and the booking agents; the confirmation of the cruise line actually constitutes the formation of a contract between the passengers and the cruise lines. Passenger Ticket or similar document which enables the passengers to get on board the ship is the evidence of such a contract. ${ }^{3}$

The contractual relationship between the passenger and the cruise line may be established by a cruise passenger contract between them or by booking confirmation of the cruise line incorporating booking conditions. In whichever situation, the cruise passenger contract is actually adopted unilaterally by the cruise line without the participation of any passenger. As such, while the contract will normally set down rights and obligations of the parties, it may limit the passengers' rights and the carriers' liabilities (Peltz, 2012), as the important notice of the Royal Caribbean International says, "Your guest ticket contract contains important limitations on the rights of passengers. It is important that you carefully read all terms of this contract, paying particular attention to section 3 , section 6 and sections 9 through 11, which limit our liability and your right to sue"4. The contract may include a law and jurisdiction clause choosing the governing law and court to settle any disputes arising from the contract. For example, you will find such a clause in the passenger contract of the Princess Cruises, "the Contract shall be between Princess and the Passenger on the basis of these Con-

${ }^{1}$ No 2336 Civil Judgement (2016) by Shanghai Maritime Court (hu72minchu2336 hao). ${ }^{2}$ [2017] EWCACiv 2222; [2018]1 Lloyd's Rep. 607.

${ }^{3}$ See Art.110 of Maritime Code of the People's Republic of China.

${ }^{4}$ Guest Ticket Contract incorporating the Guest Conduct Policy and Refusal to Transport Policy: https://www.rcclchina.com.cn/content/brand/passenger/repeat. 
ditions and the information contained in the brochure or website, and shall be governed by English law and the non-exclusive jurisdiction of the English courts." The booking conditions may also incorporate the Athens Convention, as in the "Norwegian Jade": "The provisions of the Convention Relating to the Carriage of Passengers and their Luggage by Sea 1974... ('2002 Athens Convention') apply to the cruise element of your holiday as well as the process of getting on or off the ship concerned"'.

Contractual provisions either limiting the passengers' right or limiting the carriers' liabilities may directly or indirectly result in serious injustice to the passengers. As in making contract with a cruise line or its agent, the passengers do not have any bargaining power to change the term of the contract; and once they are on board the cruise ship, their safety largely depends on the navigation and management of the ship. Thus, it is necessary and of vital importance to discuss the legal protection for the cruise passengers, which largely depends on the applicable law, either international convention or domestic law. This paper will firstly discuss the application of Athens Convention Relating to the Carriage of Passengers and their Luggage by Sea, 1974 (the Athens Convention 1974) to cruise passenger's claim from a comparative viewpoint; it will then focus on the direct effect and supremacy of the Athens Convention 1974, which exclude the need for choice of law; the following part will discuss the validity of jurisdiction clause under the Athens Convention 1974; the final part is a short conclusion.

\section{The Application of the Athens Convention 1974 to Cruise Travel}

\subsection{The Athens Convention and Its Protection for Passengers}

The Athens Convention 1974 is an important convention which establishes a regime of liability for passengers carried on seagoing vessels, but allows carriers to limit their liability. It provides for liability of the carrier and performing carrier, limit of liability and loss of right to limit liability, competent jurisdiction etc. (Berlingieri, 2014). More important is its mandatory application for the protection of the passengers which invalidates contractual provisions limiting the passengers' rights under the Athens Convention 1974. Art.18 of the Athens Convention 1974 reads as following:

\footnotetext{
"Any contractual provision concluded before the occurrence of the incident which has caused the death of or personal injury to a passenger or the loss of or damage to his luggage, purporting to relieve the carrier of his liability towards the passenger or to prescribe a lower limit of liability than that fixed in this Convention except as provided in paragraph 4 of Article 8, and any such provision purporting to shift the burden of proof which rests on the carrier, or having the effect of restricting the option specified in paragraph 1 of Article 17, shall be null and void, ...”

${ }^{5}$ Clause 2 of Passage Contract (CARNIVAL PLC TRADING AS PRINCESS CRUISES BOOKING CONDITIONS): https://www.princess.com/legal/passage_contract/index.html.

${ }^{5}$ [2017] EWCACiv 2222; [2018] 1 Lloyd's Rep. 607,610 [16].
} 
Accordingly, if the contractual provision provides higher protection to the passengers than that provided by the Athens Convention 1974, e.g. higher limit of liability or wider choice of courts, that provision will be enforceable. Otherwise, if the contractual provision limits the rights of the passengers in violation of the Athens Convention 1974, that provision will be deemed null and void. Instead, the rules in the Athens Convention 1974 will be applied to determine the relevant issues.

There are three protocols to amend the Athens Convention 1974: Protocol to the Athens Convention Relating to the Carriage of Passengers and their Luggage by Sea, 1974 (the 1976 Protocol), Protocol of 1990 to the Athens Convention Relating to the Carriage of Passengers and their Luggage by Sea, 1974 (the 1990 Protocol) and Protocol of 2002 to the Athens Convention Relating to the Carriage of Passengers and their Luggage by Sea, 1974 (the 2002 Protocol), but the 1990 Protocol didn't come into effect and was superseded by the 2002 Protocol. By 16 August, 2018, the Athens Convention 1974 has 25 Contracting States, among whom 17 States are Parties to the 1976 Protocol, the 2002 Protocol has 28 Contracting States who are not parties to or have denounced the 1974 Conven-

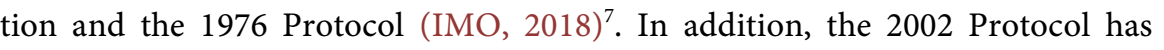
been ratified by the European Union in 2011, it has been incorporated into European Law even earlier by the Regulation (EC) No 392/2009 of the European Parliament and of the Council of 23 April 2009 on the Liability of Carriers of Passengers by Sea in the Event of Accidents, thus has been actually in effect in the member states of the European Union since 31 December 2012 (Soyer \& Leloudas, 2018). ${ }^{8}$

The 2002 Protocol increased burden on carriers and their insurers and therefore increased protection for the passengers (Soyer, 2002). The 2002 Protocol provides higher protection to passengers suffered loss as a result of death or personal injury caused by a shipping incident in that it imposed strict liability on the carrier for loss not exceeding 250,000 units of account "unless he proves that the incident: 1) resulted from an act of war, hostilities, civil war, insurrection or a natural phenomenon of an exceptional, inevitable and irresistible character; or 2) was wholly caused by an act or omission done with the intent to cause the incident by a third party", and for loss exceeding that amount the carrier shall be further liable unless he proves that the incident which caused the loss occurred without his fault or neglect ${ }^{9}$. Strict liability of the carrier for shipping incident ensures a minimum level of compensation for the passengers who suffered loss from the incident. To ensure compensation for the passengers, the 2002 Protocol added compulsory insurance as Art.4bis. In addition, the 2002 Protocol greatly increased the limit of liability for death and personal injury to 400,000 units of ${ }^{7}$ http://www.imo.org/en/About/Conventions/StatusOfConventions/Documents/Status\%20-\%20201 8.pdf.

${ }^{8}$ See Art.12 of Regulation (EC) No 392/2009 of the European Parliament and of the Council of 23 April 2009 on the Liability of Carriers of Passengers by Sea in the Event of Accidents: https://eur-lex.europa.eu/legal-content/EN/TXT/?qid=1535451632692\&uri=CELEX:32009R0392. ${ }^{9}$ See Art. 3 (1) of the 2002 Protocol. 
account per passenger on each distinct occasion, which is more than 8.5 times of the limit (46,600 units of account) under the 1976 Protocol. Therefore, while the Athens Convention 1974 unified certain important rules relating to the carriage of passengers and their luggage by sea, and its duly application will avoid the conflicts of rules of the Contracting States and will provide certain minimum protection to the passengers, the 2002 Protocol to the Convention provides much higher protection to the passengers than the 1976 Protocol.

The Athens Convention 1974 provides for its application "to any international carriage if: 1) the ship is flying the flag of or is registered in a State Party to this Convention, or 2) the contract of carriage has been made in a State Party to this Convention, or 3) the place of departure or destination, according to the contract of carriage, is in a State Party to this Convention." ${ }^{10}$ It defines "international carriage" as "any carriage in which, according to the contract of carriage, the place of departure and the place of destination are situated in two different States, or in a single State if, according to the contract of carriage or the scheduled itinerary, there is an intermediate port of call in another State"11.

Both China and the United Kingdom are Contracting Parties to the Athens Convention 1974, their application of the Convention to cruise travel differed to some degree, and worth further discussion.

\subsection{The Application of the Athens Convention 1974 in China}

China is a Contracting Party to the Athens Convention 1974 and its 1976 Protocol. There is no specific legislation incorporating or transforming Athens Convention 1974 into Chinese law, but Chapter 5 (Contract for Carriage of Passengers by Sea) of the Maritime Code of the People's Republic of China (Chinese Maritime Code) was modeled after the Athens Convention 1974 and the 1976 Protocol and its regime of liability is the same as the 1976 Protocol $(\mathrm{Wu}, 1996)^{12}$ There are not many reported cases which directly applied the Athens Convention 1974, Miss Yang v Carnival PLC ${ }^{13}$ is the most recent case which partly applied this Convention.

In Miss Yang v Carnival PLC, there was no choice of law agreement between the parties, the parties all agreed to determine the applicable law by applying Art.44 of the Law of the People's Republic of China on the Applicable Law for Civil Relationship with Foreign Elements (the Chinese Law on Applicable Law), but disagreed on the interpretation of Art.44 on the definition of place of tort. Miss Yang was drowned to unconsciousness in the swimming pool of the Cruise

\footnotetext{
${ }^{10}$ Art. 2 of the Athens Convention 1974.
}

${ }^{11}$ Art. 1(9) of the Athens Convention 1974.

${ }^{12}$ See Art. 114-Art.118 of Chinese Maritime Code. Art.114 provides for the liability of the carrier and the burden of proof, which is the same as Art.3 of the Athens Convention 1974; Art.115 provides for the contributory fault of the passengers which is the same as Art.6 of the Athens Convention 1974; Art.116 provides for valuables which is the same as Art.5 of the Athens Convention 1974; Art.117 provides for limit of liability which is the same as Art.7 and Art.8 of the Athens convention as amended by the 1976 Protocol; Art.118 provides for loss of right to limit of liability which is the same as Art.13 of the Athens Convention 1974.

${ }^{13}$ No 2336 Civil Judgement (2016) by Shanghai Maritime Court (hu72minchu2336 hao). 
ship when the ship was at high sea. The plaintiff pleaded for the application of English law as the law of the flag of the ship, but the defendant argued for the application of Chinese law and the Athens Convention 1974. In determining the law applicable to the claim, Shanghai Maritime Court did not mention the application of the Athens Convention 1974. Instead, the Court held that the applicable law could not be determined by Art.44 of the Chinese Law on Applicable Law as the parties did not have common habitual residence and the incident happened at high sea which is not governed by law of any state, therefore the applicable law shall only be determined by the general rule embodied in Art.2 of the Chinese Law on Applicable Law to apply the law which has closest connection with the incident, that is Chinese Law. However, in determining the liability of the defendant carrier, the Court did not apply rules in Chapter 5 of Chinese Maritime Code relating to carriage of passengers by sea, instead, the Court applied rules in the Tort Law of the People's Republic of China. Nevertheless, the Court did say there was a contract of carriage of passengers by sea between the plaintiff and the defendant and held that the carrier was a "performing carrier" who shall have the legal right to limit liability, then applied Art.13(1) of the Athens Convention 1974 to deny the defendant's right to limit liability. ${ }^{14}$

In reading the judgement, I found it really strange that the Court didn't apply Art.3 or Art.4 of the Athens Convention 1974 to determine the liability of the defendant carrier but applied Art.13 to determine the loss of the right to limit liability. All the necessary elements for the application of the Athens Convention 1974 and its 1976 Protocol were met in this case: 1) China is a Contracting Party, 2) the contract has been made in China, 3) the port of departure and destination were in China but the ship called at intermediate ports of South Korea and Japan. The Athens Convention 1974 shall have been applied not only in determining the loss of the right to limit liability but in determining the liability of the carrier as well. Such a strange application of the Athens Convention 1974 and the failure to apply rules relating to carriage of passengers by sea under Chinese Maritime Code led to my conclusion that the Court did not regard the carriage of passengers by cruise line as "carriage of passengers" under the Athens Convention 1974 and under Chinese Maritime Code. Indeed, there is paper specifically arguing for differentiation of cruise contract from passenger contract by sea (Guo, 2016).

The partial application of the Athens Convention 1974 by Shanghai Maritime Court in Yang v Carnival PLC is inappropriate. Firstly, whether it is a cruise only arrangement or a travel package including cruise tour, as long as there is cruise tour at sea, there is a carriage of passengers by sea. The fact that the cruise line provides much more services on board the cruise ship than ordinary carriage of passengers, that the purpose of the carriage is not or not simply to transport the passengers from a place to another place but to make the life on board a cruise ship a vacation or part of a vacation package, that the port of departure and the port of destination are the same, will not change the essential relationship of car-

${ }^{14}$ See No 2336 Civil Judgement (2016) by Shanghai Maritime Court (hu72minchu2336 hao). 
riage of passengers between the cruise line and the passengers. In Miss Yang $\mathrm{v}$ Carnival PLC, Shanghai Maritime Court had to admit that "although there was no contract evidenced by passenger ticket, there were actually a contractual relationship between the parties for the carriage of passenger by sea"15. The same rules shall be applied to determine the carrier's liability for passengers whether the carrier is a cruise line or an ordinary carrier, otherwise, the cruise passengers may be deprived of the protection provided by the Athens Convention 1974. Secondly, when the Athens Convention 1974 was applicable, the Court chose and applied Chinese law to govern the liability of the carrier but applied the Athens Convention 1974 to limit of liability, such an optional and arbitrary application of the Athens Convention 1974 is unjustifiable and without rationality. Thirdly, failure to apply rules relating to the carrier's liability for passengers but only applying rules relating to limit of liability would result in injustice and unfairness to the cruise passengers, as the limit of liability under the 1976 Protocol is much too low, it is the part of the Athens Convention 1974 that is for the protection of the carrier. In fact, the judgement in Miss Yang v Carnival PLC would cause a confusion in the application of the Athens Convention 1974.

\subsection{The Application of the Athens Convention 1974 in the United Kingdom}

The United Kingdom was Contracting Parties to the Athens Convention 1974 and the 1976 Protocol and has incorporated the Convention into English law by section 183 of the Merchant Shipping Act 1995. The Athens Convention 1974 has also been extended to govern domestic carriage of passengers in the United Kingdom by the Carriage of Passengers and their Luggage by Sea (Domestic Carriage) Order 1987 which extended the applicability of the Convention to "any contract under which the places of departure and destination are in the area consisting of the United Kingdom, the Channel Islands and the Isle of Man and under which there is no intermediate port of call outside that area." 16 The United Kingdom ratified the 2002 Protocol and denounced the Athens Convention 1974 and the 1976 Protocol, ${ }^{17}$ and the 2002 Protocol has been incorporated into English law by the Merchant Shipping (Convention Relating to the Carriage of Passengers and their Luggage by Sea) Order 2014. Reported cases illustrated that, in the United Kingdom, the Athens Convention 1974 was consistently applied to carriage of passengers by cruise line as well as by ferry ship, to domestic carriage of passengers as well as international carriage of passengers.

In David v Stena Line Limited ${ }^{18}$, a passenger Mr. Michael David fell overboard from the "ro-ro" ferry Koningin Beatrix owned and operated by the defendant during the course of her passage from Rosslare in the Irish Republic to Fish${ }^{15} \mathrm{Ibid}$.

${ }^{16}$ Art.2 of the Carriage of Passengers and their Luggage by Sea (Domestic Carriage) Order 1987: http://www.legislation.gov.uk/uksi/1987/670/article/2/made.

${ }^{17}$ http://www.imo.org/en/About/Conventions/StatusOfConventions/Documents/Status\%20-\%20201 8.pdf.

${ }^{18}$ [2005] EWHC 420 QB; [2005] 1Lloyd's Rep. 13. 
guard in Wales and was drowned before being rescued. Mr. Davis's widow brought a claim under the Fatal Accidents Act 1976 and the Law Reform (Miscellaneous Provisions) Act 1934, but the Court held "travel by ferry from the Republic of Ireland to the United Kingdom is governed by the Athens Convention..., as set out in Schedule 6 to the merchant Shipping Act 1995"19 and that "notwithstanding the fact that Mr. Davis was in the sea, rather than on board Koningin Beatrix, when he met his death, it is now common ground and the parties are agreed that he died during the course of carriage within the meaning of the Convention and that the Convention therefore applies"20.

In Darkins v Carnival ${ }^{21}$, the claimant was a passenger on the defendant's cruise ship Oriana, on 23 November 2006, while the ship was in international waters, she was walking through the Conservatory Restaurant at about 14:00 when she fell, injuring her knees and wrists. Lord justice PILL held in his judgement that "the claim was pleaded under the Occupiers' Liability Act 1957 but it is common ground that it was governed by the Athens Convention relating to the Carriage of Passengers and their Luggage by Sea 1974... This was 'international carriage' of a passenger pursuant to a contract of carriage within the Convention"22.

In the "Norwegian Jade"23, the claimant was a cruise passenger on board the Norwegian Jade, while disembarking for shore excursion, he sustained injury and loss after tripping over a hazardous step whilst aboard a tender boat owned and operated by the Boatmen Union of Santorini in the Greek port of Santorini. The claimant sought compensation contending that the incident occurred during the course of international carriage and that the Athens Convention relating to the Carriage of Passengers and their luggage by Sea 1974 applied, and the defendant was at fault or in neglect under article 3 of the Convention. The Courts held that the defendant was the "contractual carrier" under the Athens Convention, the trip occurred in the "course of carriage" and the defendant was guilty of /responsible for fault or neglect by failing to adequately mark or give warning of the step ${ }^{24}$.

In Michael v Musgrave (Trading as YnysRibs) (the "Sea Eagle") ${ }^{25}$, the claimant was one of a party of visitors being taken on a trip around the coast of Anglesey in the rigid inflatable boat (RIB) Sea Eagle to observe areas of scenic and wildlife interest, when the RIB was in the Menai Strait, and as the claimant was standing up, the RIB hit a wave and the claimant was thrown about, sustaining injury. More than two and half years later, the claimant issued proceedings against the defendant alleging negligence. Although the trip was not an international carriage, the Athens Convention 1974 was held applicable as it was extended to ${ }^{19}$ Ibid, [2].

${ }^{20}$ Ibid, [4].

${ }^{21}$ [2011] EWCACiv 1237; [2012] 1 Lloyd's Rep. 1.

${ }^{22}$ Ibid, [2].

${ }^{23}$ [2017] EWCACiv 2222; [2018] 1 Lloyd's Rep. 607.

${ }^{24}$ Ibid.

${ }^{25}$ [2011] EWHC 1438 (Admlty); [2012] 2 Lloyd's Rep. 37. 
domestic carriage. As the Sea Eagle was held to be a seagoing ship for the purposes of the Convention, the Convention was applied to time-bar the claim.

It can be concluded from above cases that the application of the Athens Convention 1974 by the English Courts tends to provide equal protections to passengers of cruise line and ferry, including both international carriage and domestic carriage. Comparing with the approach taken by Shanghai Maritime Court in Miss Yang v Carnival PLC, the application of the Athens Convention 1974 by the English Court is more rational and in conformity with the purpose of the Convention.

\section{The Application of the Athens Convention 1974 and Choice of Law}

The Athens Convention 1974 includes both substantive rules governing the liability of carrier to passengers and procedural rules governing jurisdiction of court over disputes between carrier and passengers. Its duly application will avoid conflict of jurisdictions and conflict of laws among the Contracting Parties (Han, 2014).

\subsection{Direct Effect and Applicability of the Athens Convention 1974}

Like any other international convention, the Athens Convention 1974 is the result of agreement of sovereign states, it could not enter into effect without prescribed numbers of ratifying states. After the Convention entered into effect, the Contracting States are obliged to give effect to it, but the means of giving effect is left to the Contracting States (Li, 2003).

In the United Kingdom, international conventions do not have direct effect and could not be applied by English Courts without the Parliament legislation given them force of law (Li, 2003). Thus, the Athens Convention 1974 and the 1976 Protocol were given force of law in the United Kingdom by section 183 of the Merchant Shipping Act 1995, although the Convention entered into force for the United Kingdom on 28 April 1987 and the Protocol of 1976 on 30 April 1989. And with the entering into effect of the 2002 Protocol on 23 April 2014, the Merchant Shipping (Convention Relating to the Carriage of Passengers and their Luggage by Sea) Order 2014 was made on 27 May 2014 to modify Schedule 6 to the Merchant Shipping Act 1995. The Athens Convention 1974 as duly incorporated into English law would therefore be capable of being applied by English Courts.

In China, there is no similar domestic legislative process to give force of law to international convention in the territory. Accordingly, there is no legislation specifically made for incorporating the Athens Convention 1974 and the 1976 Protocol into Chinese law. The fact that Chapter 5 of Chinese Maritime Code was modeled after the Athens Convention 1974 and the 1976 Protocol did not have the legal effect of giving force of law to the Athens Convention in China since the Chapter did not have any words to such effect. The only effect of such 
arrangement is making Chinese Maritime Code relating to carriage of passengers in conformity with the Athens Convention 1974 and the 1976 Protocol. Consequently, the Athens Convention 1974 and the 1976 Protocol shall have direct effect in China since 30 August 1994, the effective date of the Convention on China, and the Chinese Courts shall from then on directly apply the Convention when it is applicable.

\subsection{Priority of the Application of the Athens Convention 1974}

For various reasons, the plaintiff passenger may plead his claim against the carrier under a domestic law which may have the same or different rules as those in the Athens Convention 1974. Shall the court apply the Athens Convention 1974 or domestic law with or without a choice of law process?

The English Courts obviously will apply the Athens Convention 1974 as long as it is applicable, as they did in the Dawkins $v$ Carnival $^{26}$ where the plaintiff pleaded the claim under the Occupier's Liability Act 1957 and in Davis v Stena Line Limited ${ }^{27}$ where the claim was brought under the Fatal Accidents Act 1976 and the Law Reform (Miscellaneous Provisions) Act 1934.

In contrast, in Miss Yang v Carnival PLC ${ }^{28}$ where the plaintiff argued for the application of English law and the defendant pleaded for the application of Chinese law and the Athens Convention 1974, Shanghai Maritime Court went on a choice of law process according to rules in the Chinese Law on Applicable Law and determined Chinese law as the governing law, but also applied the Athens Convention 1974 in determining the limit of liability of the carrier.

In applying the Athens Convention 1974 to the dispute in Miss Yang v Carnival PLC, Shanghai Maritime Court might have followed the interpretation of the Supreme People's Court relating to the application of international conventions. There is a provision relating to the application of international convention in Chapter 8 (Applicable Law for Civil Relations with Foreign Element) of the General Principle of Civil Law of the People's Republic of China (the General Principle of Civil Law), that is paragraph 2 of Art.142 which says, "if any international treaty concluded or acceded to by the People's Republic of China contains provisions different from those in the civil laws of the People's Republic of China, the provisions of the international treaty shall apply, unless the provisions are ones on which the People's Republic of China has announced reservations." When Chapter 8 was replaced by a specific Law-the Chinese Law on Applicable Law, there is nowhere to find equivalent provision of Art.142 in this new law, that is to say, Art.142 has been discarded. However, the Supreme People's Court in its interpretation of this new law restated the provision of Art.142, saying that "when the application of law for civil relationship with foreign elements refer to the application of international convention, the People's Court shall act in accordance with paragraph 2 of Art.142 of the General Prin-

${ }^{26}$ [2011] EWCACiv 1237; [2012] 1 Lloyd's Rep. 1.

${ }^{27}$ [2005] EWHC 420 QB; [2005] 1 Lloyd's Rep. 13.

${ }^{28}$ No 2336 Civil Judgement (2016) by Shanghai Maritime Court (hu72minchu2336 hao). 
ciple of Civil Law..."29.

Under paragraph 2 of Art.142 of the General Principle of Civil Law, the application of international convention will be secondary to domestic law: the People's Court shall first apply rules in domestic law, if there are different rules in international convention, then such different rules shall be applied, otherwise, no need to apply international convention. Such an approach to the application of international convention is inappropriate and problematic.

Firstly, when an international convention is applicable, applying the same rules in domestic law may lead to the same result but would never be regarded as China's performance of its treaty obligation to give effect to international convention it ratified. Failure to apply international convention by the Courts will obviously be regarded as or be presumed to be a failure of the State to give effect to international convention.

Secondly, only applying different rules in international convention may make the application of law process very complicated, as the Court shall first compare domestic law with relevant international convention in order to decide whether there is any difference, then the Court may have to apply rules of domestic law and rules of international convention which are different from domestic law. When simply applying the international convention will be enough and enough, why bothering to make such comparison and segregate the application of law? In Miss Yang v Carnival PLC, the Athens Convention 1974 could have been applied to decide both the liability of the carrier and limit of liability or loss of right to limit of liability.

Thirdly, this approach will inappropriately limit the application of substantive international convention. Under private international law, the law applicable to civil matters with foreign element will not always be domestic law, there shall be a choice of law process - applying choice of law rules to choose the governing law. If the choice of law rule leads to the application of a foreign law, there will be no room for the application of international convention according to paragraph 2 of Art.142 of the General Principle of Civil Law. Such a choice of law process will then result in the loss of chance for the international convention to be applied to a case under the scope of its application. If the relevant international convention has been incorporated into the foreign law, the application of the foreign law may probably lead to the application of the convention, then why bothering to make the choice when the relevant international convention is applicable in the first place?

Fourthly, the result of the choice of law process is either to apply the domestic law or foreign law, if there is no unified choice of law rules, the result of choice will be different in different jurisdictions, possibly leading to the plaintiff's forum shopping. If there is international convention uniformly applied by the relevant jurisdictions, there is no need for the parties to choose the jurisdiction

\footnotetext{
${ }^{29}$ Art.4 of the Interpretation of the Supreme People's Court's on Several Issues Relating to the Application of Law of the People's Republic of China on Applicable Law for Civil Relation with Foreign Element (I), fashi[2012]24hao.
} 
and there is no need for the court to choose applicable law. Simply applying the relevant applicable international convention will benefit all parties: the plaintiffs do not need to make comparison of the laws of different jurisdictions to make a forum shopping, the courts do not need to undergo the choice of law process to find the applicable law. It will also ensure the certainty of application of law and the reasonable expectation of the parties.

Fifthly, mandatory international convention aims not only to unify national laws but to provide minimum protection to the weaker parties in civil and commercial activities, failure to apply such convention will probably deprive the weaker party of their protection under the relevant international convention. The Athens Convention 1974 is such a convention where the minimum protection for the passengers shall not be contracted out by the parties. Similarly, the Court shall not be allowed to apply domestic law in replacement of the Athens Convention 1974, with or without choice of law process in case the protection purpose of the Athens Convention 1974 be frustrated.

In conclusion, paragraph 2 of Art.142 of the General Principle of Civil Law should be discarded. It might have been the reason why it was not repeated in the Chinese Law on Applicable Law. The Supreme People's Court ought not have picked it up again. Therefore, it is suggested that the Athens Convention 1974 and the 1976 Protocol shall have priority in its application to regulate the carrier's liability to passengers when it is applicable in Chinese Courts no matter under whatever law the plaintiff makes his claim. It is the duty of the People's Court to ensure the application of the Athens Convention 1974 and the 1976 Protocol for the protection of passengers as well as for the performance of China of its treaty obligation.

\subsection{The Validity of Choice of Law Agreement}

Passengers contract may incorporate the application of the Athens Convention 1974, the 1976 Protocol or the 2002 Protocol or choose a domestic law as governing law. Due to the fact that the Athens Convention 1974, the 1976 Protocol and the 2002 Protocol are all mandatory for the protection of the passengers in international carriage of passengers by sea, the parties do not enjoy the right to opt out the application of the Convention. Where the Athens Convention 1974, the 1976 Protocol or the 2002 Protocol is applicable, the courts of the Contracting State shall apply the Convention in the first place, they shall not apply domestic law in replacement of the Convention or apply the choice of law rules to choose the governing law $^{30}$. Therefore, the parties' choice of law, which may be permitted under the relevant private international law, ${ }^{31}$ shall not be considered by the Courts of Contracting Parties where the disputed issues are governed by the Athens Convention 1974.

However, as only contract provisions which deprive the passengers of their ${ }^{30}$ See discussion in 3.2 of the main text.

${ }^{31}$ For example, the Chinese Law on Applicable Law permits the parties to choose the governing law for both contractual obligations (Art.41) and tort obligations (Art.44). 
protection provided by the Athens Convention 1974, the 1976 Protocol or the 2002 Protocol as applicable will be null and void, the parties are actually encouraged to provide better protection to the passengers than that of the Athens Convention 1974 and the Protocols. If the law chosen by the parties provides better protection to the passengers, such as where the court has a duty to apply the 1976 Protocol but the parties has chosen the law of a state where the 2002 Protocol has been given force of law, e.g. the clause in the passenger contract of the Princess Cruises which chose English law as the governing law ${ }^{32}$, or where the parties incorporated the 2002 Protocol into the passenger contract, e.g. the booking conditions in the "Norwegian Jade" case ${ }^{33}$, shall the court apply the 2002 Protocol instead of the 1976 Protocol?

Given that the purpose of the Athens Convention 1974 is to provide minimum protection for the passengers, the contents of the chosen law might be regarded as contract provisions relating to the rights and obligations of the parties and be enforced. Such an approach may be accepted by the Supreme People's Court, as it says in its interpretation of the Chinese Law on Applicable Law that "where the parties refer to the international convention not yet effective on People's Republic of China, the People's Court may determine the rights and obligations of the parties according to the contents of such international convention, ..."34. Therefore, where there is a reference to the 2002 Protocol in the passenger contract, the People's Court could determine the rights and obligations of the parties according to the 2002 Protocol, e.g. applying a higher limit of liability.

\section{The Validity of Jurisdiction Clause in Cruise Passenger Contract}

Cruise Line will normally include a law and jurisdiction clause or simply a jurisdiction clause in the passenger contract. For example, there is a law and jurisdiction clause in the passenger contract of the Princess Cruises ${ }^{35}$; and there is a jurisdiction clause in the Guest Ticket Contract incorporating the Guest Conduct Policy and Refusal to Transport Policy of the Royal Caribbean International which provides that

"For personal injury, illness or death of a passenger, it is agreed by and between passenger and carrier that all disputes and matters whatsoever arising under, in connection with or incident to this agreement, passenger's cruise, cruise tour, land tour or transport, shall be litigated, if at all, in and before a competent Chinese court in Shanghai. Passenger hereby consents to jurisdiction and waives any venue or other objection that he may have to any

\footnotetext{
${ }^{32}$ See footnote 5 and its main text.

${ }^{33}$ See footnote 6 and its main text.

${ }^{34}$ Art.9 of the Interpretation of the Supreme People's Court's on Several Issues Relating to the Application of Law of the People's Republic of China on Applicable Law for Civil Relation with Foreign Element (I), fashi[2012]24hao.

${ }^{35}$ See footnote 5 and its main text.
} 
such action or proceeding being brought in the applicable court located in Shanghai." 36

Whether jurisdiction clause is combined with choice of law clause or not, it will limit the passenger' s right he/she would otherwise be entitled to under relevant civil procedural law to choose the court after the dispute has arisen, and the chosen jurisdiction may apply a rule of law which is less favorable to the passengers. The jurisdiction chosen may or may not be the Contracting State of the Athens Convention 1974. If it is, the Athens Convention 1974 may be duly applied and its mandatory protection for the passengers would not be evaded, e.g. the choice of English law and English jurisdiction in the passenger contract of the Princess Cruises will lead to the application of the Athens Convention 1974, now the 2002 Protocol. However, if the chosen jurisdiction, though Contracting State of the Athens Convention 1974, did not accede to the 2002 Protocol, and if the passengers are entitled to choose the jurisdictions which would apply the 2002 Protocol, the passengers are actually deprived of the better protection provided by the 2002 Protocol because of the jurisdiction clause, e.g. if the passengers could choose the jurisdiction of the United Kingdom where the 2002 Protocol is applicable, the jurisdiction clause choosing Chinese court in the Guest Ticket Contract incorporating the Guest Conduct Policy and Refusal to Transport Policy of the Royal Caribbean International would deprive the passengers of their protection provided by the 2002 Protocol. In addition, if the chosen jurisdiction is not Contracting State of the Athens Convention 1974, as it does not have the obligation to apply the Convention, it will choose the governing law according to its private international law, the chosen law may be more favorable to the carrier than the Athens Convention 1974 if there is no limit of liability for the carrier, but it may also be less favorable to the passengers if there is no mandatory rule invalidating contractual provisions limiting the rights of the passengers or limiting the liability of the carriers. Jurisdiction is closely connected with choice of law and thus has great impact on the interest and benefits of the passengers.

If the passenger is not satisfied with a jurisdiction clause and want to sue in another jurisdiction which could provide better protection to his/her interest, is he/she able to do so?

Under paragraph 1 of Art.17 of the Athens Convention 1974, the claimant could choose one of the following courts to bring an action arising under the Convention: "1) the court of the place of permanent residence or principal place of business of the defendant, or 2) the court of the place of departure or that of the destination according to the contract of carriage, or 3 ) a court of the State of the domicile or permanent residence of the claimant, if the defendant has a place of business and is subject to jurisdiction in that State, or 4) a court of the State where the contract of carriage was made, if the defendant has a place of business

${ }^{36}$ Art.9(a) of Guest Ticket Contract incorporating the Guest Conduct Policy and Refusal to Transport Policy: https://www.rcclchina.com.cn/content/brand/passenger/repeat. 
and is subject to jurisdiction in that State." Paragraph 2 of Art.17 of the Athens Convention 1974 allows the parties to make an agreement to submit the claim for damages to any jurisdiction or to arbitration, but this agreement could only be made after the occurrence of the incident which has caused the damage. ${ }^{37}$ Therefore, a jurisdiction clause in a cruise passenger contract of whatever form which was made before the occurrence of the incident will not be given effect under the Athens Convention 1974 (Waldron, 1991). Furthermore, if the jurisdiction clause in a cruise passenger contract has "the effect of restricting the option specified in paragraph 1 of Article 17", it shall be null and void. ${ }^{38}$ Accordingly, the jurisdiction clause in both the passenger contract of the Princess Cruises and the Guest Ticket Contract incorporating the Guest Conduct Policy and Refusal to Transport Policy of the Royal Caribbean International will be null and void under the Athens Convention1974.

The limitation on party autonomy in choice of court by the Athens Convention 1974 is of great significance for the protection of the interest of the cruise passengers, as it protects the cruise passengers against unfair jurisdiction clause and ensures their rights of choice. In drafting or adopting a jurisdiction clause in cruise passenger contract, the cruise line would normally do so in its best interest resulting in detriment to the interests of the passengers, but the passengers could do nothing about it. Under the Athens Convention 1974, if the jurisdiction clause leads to his/her best interest, the cruise passenger could accept it after all after the occurrence of the incident by bringing action in the chosen court, otherwise, he/she could bring action in another competent court. After the occurrence of the incident causing damage the cruise line and the cruise passenger could reach a jurisdiction agreement to submit their disputes to any jurisdiction or to arbitration, since at that time the passenger would be able to better assess the effect of choosing a court whether at his option or by jurisdiction agreement.

There is no such limitation under Chinese Law. Under the 2012 Civil Procedural Law of the People's Republic of China (the 2012 CPL), a jurisdiction clause in the passenger's contract may be given effect if the chosen court is "located in such a place having actual connection with the disputes as the place of the defendant's domicile, the place where the contract was performed or made, the place of the plaintiff's domicile, or the location of the subject matter etc." 39 There is no time restriction for the making of the jurisdiction agreement as that provided by paragraph 2 of Art.17 of the Athens Convention 1974, thus it is not possible for the passengers to challenge the validity of a jurisdiction clause in cruise passenger contract on the basis that it is not made after the occurrence of the incident. Nevertheless, the passenger may be able to avoid the jurisdiction clause as part of a standard form contract. The Supreme People's Court confirmed such option by providing in its interpretation of the $2012 \mathrm{CPL}$ that "if the

\footnotetext{
${ }^{37}$ Art.17(2)of the Athens Convention 1974 provides that "After the occurrence of the incident which has caused the damage, the parties may agree that the claim for damages shall be submitted to any jurisdiction or to arbitration." This provision has been added to Art.17 (3) in the 2002 Protocol. ${ }^{38}$ See Art.18 of the Athens Convention 1974.

${ }^{39}$ Art.34 of the 2012 Civil Procedural Law of the People's Republic of China.
} 
business dealer who adopts a standard form to make a jurisdiction agreement with the consumer has not taken reasonable measures to notify the consumer of such agreement, the court should support the consumer's argument to invalidate such jurisdiction agreement ${ }^{340}$. This provision does not make jurisdiction clause in standard form consumer contract null and void but provides the consumer with a choice whether to quash such a jurisdiction clause. However, if the business dealer could establish that he has taken reasonable measures to notify the consumer of such a jurisdiction clause, the court would hold the clause valid and enforceable. ${ }^{41}$

In comparison, the rules relating to jurisdiction agreement under the Athens Convention 1974 could provide better protection to the interest of the cruise passengers than the rules under China's Civil Procedural Law in that it is much easier for the passenger to avoid a jurisdiction clause in passenger contract.

\section{Conclusion}

Cruise travel, whether as a single arrangement or as part of a travel package, is carriage of passengers. As the Athens Convention 1974 regulates the carrier's liability for passengers and provides minimum protection to passengers, it shall be applied to international cruise passengers by the courts of the Contracting States. The application of the Convention shall have priority over domestic law, substantive law as well as private international law. Choice of law by the parties may opt out the application of the Athens Convention 1974, but if it is in favor of the passengers, the contents of the chosen law or Convention may be incorporated into the contract and be enforced as contract provisions; this will not be in violation of the Athens Convention 1974. The Athens Convention 1974 invalidates contract provisions in contradiction with its mandatory rules, and jurisdiction clause in passenger contract will normally be null and void. As China has not yet acceded to the 2002 Protocol, it is quite necessary for Chinese cruise passengers to make forum shopping if possible unless the 2002 Protocol has been incorporated into the passenger contract. I would suggest that for better protection and equal protection of cruise passengers, China shall accede to the 2002 Protocol and revise relevant contents in Chapter 5 of Chinese Maritime Code.

\section{Conflicts of Interest}

The author declares no conflicts of interest regarding the publication of this paper.

\section{References}

Berlingieri, F. (2014). International Maritime Conventions: Volume 1 the Carriage of ${ }^{40}$ Art. 31 of the Supreme People's Court's Interpretation on the Application of the Civil Procedural Law of the People's Republic of China (Fashi [2015]5, http://www.court.gov.cn/fabu-xiangqing-13241.html).

${ }^{41} \mathrm{Fu}$ Xiaoyan v Jiangsu Suning Yigou Ecommerce Co. Ltd., No 10249 Civil Ruling (2015) by the Beijing Second Intermediate People's Court (erminzhongzidi10249hao). 
Goods and Passengers by Sea (p. 260). London: Informa Law from Routledge. https://doi.org/10.4324/9781315796451

CLIA (2018). Cruise Lines International Association Updates Official 2017 Global Passenger Numbers.

https://www.cruising.org/about-the-industry/press-room/press-releases/pr/cruise-lines -international-association-updates-official-2017-global-passenger-numbers

Guo, P. (2016). A Study on Legal Nature of Cruise Contract. Chinese Journal of Maritime Law, 27, 55-62.

Han, D. P. (2014). Private International Law (p. 26). Beijing: Higher Education Press.

IMO (2018). Status of IMO Treaties: Comprehensive Information on the Status of Multilateral Conventions and Instruments in Respect of Which the International Maritime Organization or Its Secretary-General Performs Depositary or Other Functions.

http://www.imo.org/en/About/Conventions/StatusOfConventions/Documents/Status\% 20-\%202018.pdf

Li, H. P. (2003). Introduction to Law of Treaty (pp. 314-317). Beijing: Law Press.

Peltz, R. (2012). The Athens Convention Revisited. Journal of Maritime Law \& Commerce, 43, 491.

Soyer, B. (2002). Sundry Considerations on the Draft Protocol to the Athens Convention Relating to the Carriage of Passengers and Their Luggage by Sea 1974. Journal of Maritime Law \& Commerce, 33, 519.

Soyer, B., \& Leloudas, G. (2018). Carriage of Passengers by Sea: A Critical Analysis of the International Regime. Michigan State International Law Review, 26, 483.

Waldron, A. (1991). The Theory and Practice of a Carrier's Liability under the Athens Convention-The English Experience. Maritime Policy and Management, 18, 29-41. https://doi.org/10.1080/03088839100000004

Wu, H. N. (1996). Maritime Law (p. 148). Beijing: Law Press. 